DJS Vol. 42 (1) (2020) pp. 21- 31 - ISSN: 1012-5965

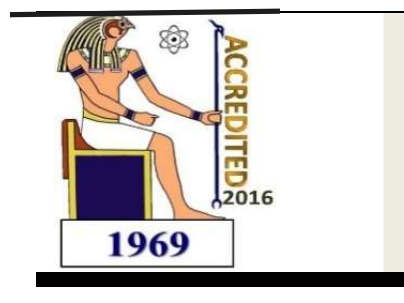

Research Article
Delta Journal of Science

Available online at

https://djs.journals.ekb.eg/

\title{
Green synthesis of silver nanoparticles from some cyanobacterial species
}

Mostafa M. El -Sheekh ${ }^{1 *}$ Saly F. Gheda ${ }^{1}$ Gehan A. Ismail ${ }^{1}$ Rehab S. Ghobashy ${ }^{1}$

1 Botany and Microbiology Department, Faculty of Science, Tanta University, Tanta, Egypt

Corresponding author*: mostafaelsheikh@science.tanta.edu.eg

\begin{tabular}{ll}
\hline KEY WORDS & ABSTRACT \\
\cline { 1 - 3 } $\begin{array}{l}\text { Cyanobacteria, } \\
\text { filtrate, biomass, }\end{array}$ & $\begin{array}{l}\text { Seven selected cyanobacterial species namely Nostoc linckia, Nostoc } \\
\text { AgNPs. }\end{array}$ \\
& $\begin{array}{l}\text { amphigranulata, Spirulina platensis and Phormidium purpurascens were } \\
\text { measured by optical density and dry weight, day after day. Spirulina }\end{array}$ \\
& platensis biomass was harvested at the $16^{\text {th }}$ day which about equaled \\
& 8.322 g/L dry biomass. Also the biomass of other selected cyanobacterial \\
& species was collected at the $22^{\text {nd }}$ day. The present work was designed for \\
& the biosynthesis of AgNPs by seven cyanobacterial species using their \\
& filtrate and biomass separately. Appearance of surface plasmon band at \\
& 400 nm for filtrate and biomass indicated the biosynthesis of AgNPs. UV- \\
& vis spectroscopy used to characterize biosynthezied AgNPs and resulted in \\
& appearance of surface plasmon band at $400 \mathrm{~nm}$ for filtrate and biomass
\end{tabular}

\section{Introduction}

Cyanobacteria "blue green algae" are a division, that descending from algae. They are considered to be the only known oxygen photobacteria prokaryotes. They are oxygenic photoautotrophs prokaryotes which presented in unicellular or multicellular forms that are presented in nearly every possible habitat on earth, that possess chlorophyll (a) and carry out oxygenic photosynthesis that associated with photosystems I and II (Hussein et al., 2017). The variety and physiology of these cyanobacteria have acquired great interest in the last few years because they considered a rich source of many bioactive compounds which serves as a brilliant base for discovering their applications in the field of biotechnology (Sinia et al., 2018; Kannaujiya et al., 2018). Cyanobacterial genera of Nostoc, Anabaena, Oscillatoria and Microcystis are considered to be a promising 
microalgae designed for the production of many bioactive natural products because they provide a wide range of secondary metabolites (Singh et al., 2017).

Nanotechnology is reforming the way we live. There is hardly any doubt that nanotechnology is very beneficial and valuable to man. Nanotechnology opens new applications in several fields including manufacturing, medicine, material science and numerous technologies (El-Sheekh and El-Kassas, 2016). Among all metallic nanoparticles, silver nanoparticles (AgNPs) have proved to be the most effective against large variety of organisms including cyanobacteria (Ahmed et al., 2015). AgNPs have been utilized in various processes in the medical field and has hence been exploited well. AgNPs have long been recognized as having an inhibitory effect on many bacterial strains and microorganisms (Phull et al., 2016). AgNPs have been utilized in various processes in the medical field and has hence been exploited well.

The present work aims to the green synthesis of AgNPs from the selected cyanobacteria species filtrate and biomass for possible use as commercial products.

\section{Materials and methods Cultivation of cyanobacterial species}

Seven cyanobacteria (blue green algae) species "Nostoc linckia, Nostoc muscorum, Oscillatoria acuminata, Anabaena variables, Oscillatoria amphigranulata, Spirulina platensis and
Phormidium purpurascens" were obtained from the culture collection, Phycology Laboratory, Botany Department, Faculty of Science, Tanta University. Spirulina platensis was cultivated in modified Zarrouk's medium (Abia and Ogawa, 1977). The other six cyanobacterial species were cultivated in BG11 (Blue-Green algae) medium (Reppika et al., 1979). Axenic cyanobacterial cultures were prepared in each sterilized liquid medium, culture flasks were then incubated under the conditions of surface light intensity of 45 $\mu$ mole photon $\mathrm{m}^{-2} \mathrm{~s}^{-1}$ at $30 \stackrel{\circ}{ } \mathrm{C} \pm 2$, supplied with a mixture of $97 \%$ dry air and $3 \% \mathrm{CO}_{2}$ to accelerate the growth of algae. The pumped air was sterilized first by passing through bacterial air filters of $0.45 \mu$ pore diameter. The cultures maintained for 7-10 days. These stock cultures were used as an inoculant in the following experiments. Each organism was cultured in $2 \mathrm{~L}$ Erlenmeyer flasks and was inoculated with $100 \mathrm{ml}$ of the stock inoculant corresponding to each species under the culture conditions mentioned above (Stainer, 1971).

Cyanobacterial cells (biomass), for each cyanobacterium culture, were harvested at the beginning of stationary phase corresponding to each species by centrifugation (Fisher Centerific Centrifuge) at $4000 \mathrm{rpm}$ for $20 \mathrm{~min}$. Pellet cells were rinsed and washed three times and resuspended in sterilized distilled water to remove traces of growth medium (Patel et al., 2018). A known weight of the algal biomass ( $g$ ) and specific volume of the supernatant (filtrate) from each species was kept until 
used for nanoparticles synthesis. The growth indices were estimated by two methods: optical density and dry weight of the resultant biomass of each algal culture.

\section{Biosynthesis of silver nanoparticles (AgNPs)}

For biosynthesis of AgNPs, both the biomass and the filtrate (cell free extract) of each cyanobacterial culture were used (El-Sheekh and El-Kassas, 2014). For the biomass, $5 \mathrm{~g}$ of each biomass were prepared in a $250 \mathrm{ml}$ Erlenmeyer flask and mixed with $95 \mathrm{ml}$ of $\mathrm{AgNO}_{3}$ solution $\left(10^{-3} \mathrm{mM}\right)$ at $\mathrm{pH} 7$ for $24 \mathrm{~h}$. For AgNPs biosynthesis using cyanobacterial filtrate, $10 \mathrm{ml}$ of each cyanobacterial filtrate were prepared in a $250 \mathrm{ml}$ Erlenmeyer flask and mixed with $90 \mathrm{ml}$ of $\mathrm{AgNO}_{3}$ solution under the same conditions. Visual appearance of a greenish to brownish color in the solutions was a clear indication for AgNPs formation of in the reaction mixture.

\section{Characterization of Silver}

\section{Nanoparticles Ultraviolet (UV) vis} Spectrometry

The bio-reduction of pure $\mathrm{Ag}^{+}$ions in aqueous solution was detected by sampling of aliquots $(0.2 \mathrm{~mL})$ of the colloidal suspension, and then diluting the samples with $2 \mathrm{~mL}$ deionized water and subsequently measuring UV-Vis spectra of the resulting diluents using Double Beam PC Scanning Spectrophotometer. The absorption maxima were scanned at the wavelength of 200-800 $\mathrm{nm}$. UV visible spectra analysis verifies the biosynthesis of AgNPs at nearly $420 \mathrm{~nm}$ as a Plasmon resonance peak characterized of silver ions.

\section{Results}

Seven selected cyanobacterial (blue green algal) species were previously identified in the laboratory of Phycology, Faculty of Science, Tanta University according to Desikachary, (1959).

\section{Determination of cyanobacterialspecies growth curve Optical densitymethod}

The results in Figure 1 (a, b, c, d, e, f \&g) indicated that the growth curve of $S$. platensis, increased progressively in the exponential phase until reached the stationary phase on $16^{\text {th }}$ day of growth after a lag phase of 2 days. The growth curves of the other six tested cyanobacteria species showed steadily increase, after a lag phase of 4 days, followed by the exponential phase until attained the stationary phase on $22^{\text {nd }}$ day. 

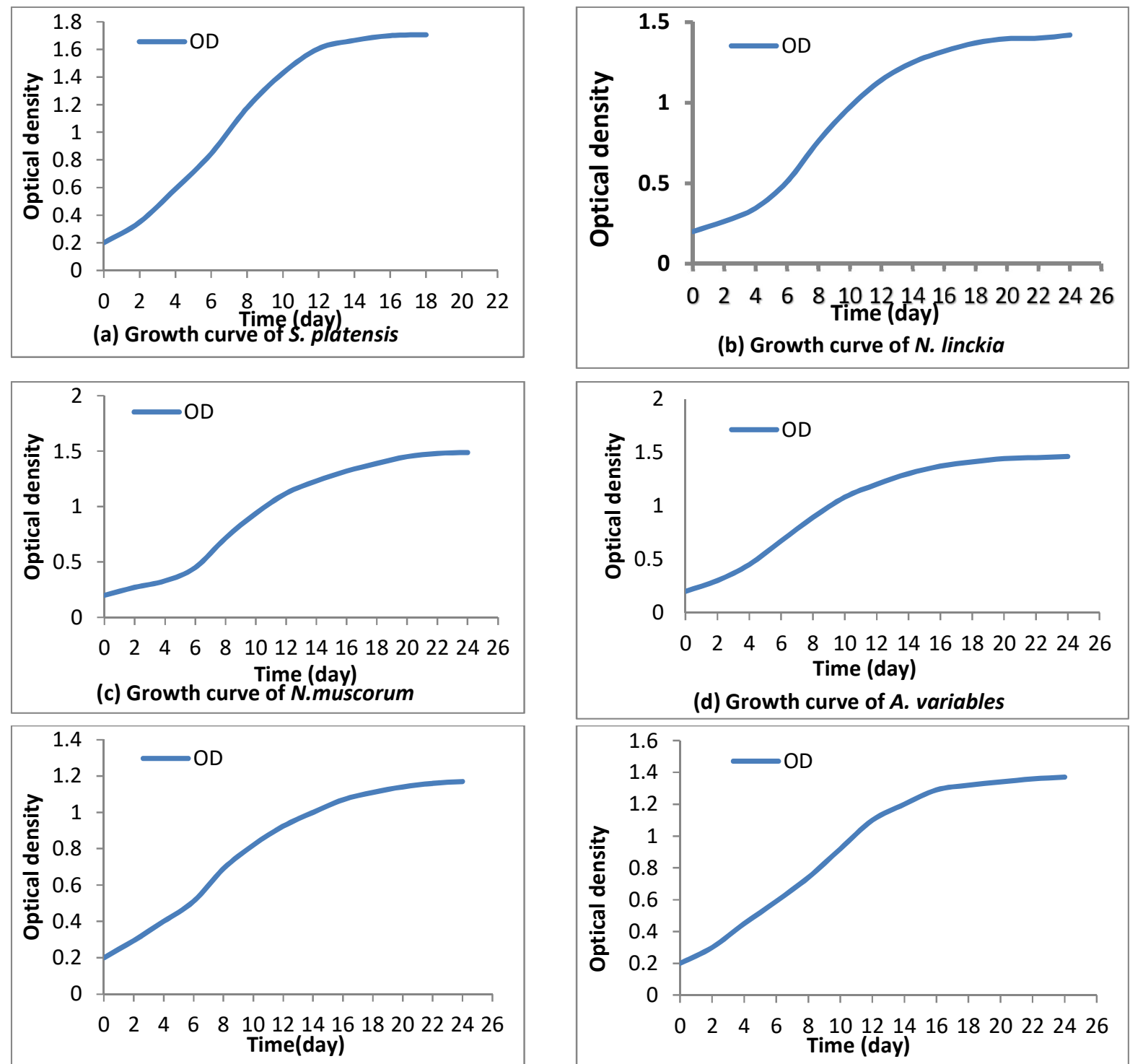

(e) Growth curve of O.acuminata

(d) Growth curve of $A$. variables
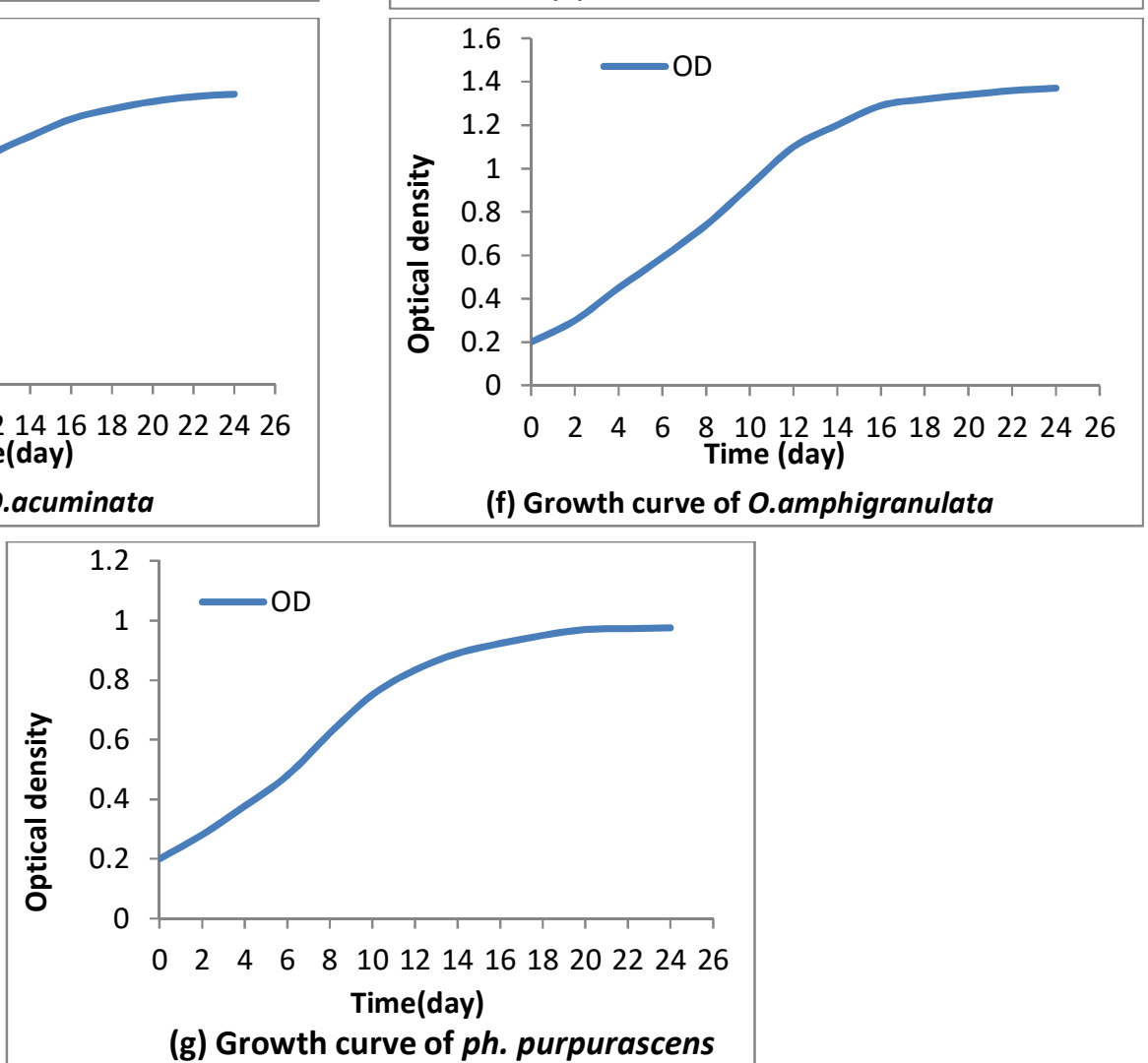

Fig.1: Growth curves of the selected cyanobacterial species using optical density method. 


\section{Dry weight method}

As shown in Table 1 the dry weight of

S. platensis reached stationary phase rapidly in $16^{\text {th }}$ days " $8.322 \mathrm{mg} / 100 \mathrm{ml}$ " rather than the other tested cyanobacterial species N. linckia recorded the highest dry weight (8.478mg/ $100 \mathrm{ml}$ ), while $O$. accuminata recorded the lowest dry weight $(6.21 \mathrm{mg} / 100 \mathrm{ml})$.

Table 1: Dry weight of the tested cyanobacterial species $(\mathrm{mg} / 100 \mathrm{ml})$

\begin{tabular}{|c|c|c|c|c|c|c|c|}
\hline & \multicolumn{7}{|c|}{ Cyanobacterial species } \\
\hline days & N. muscorum & P. purpurascens & O. acuminata & A. variables & N. linckia & $\begin{array}{c}0 . \\
\text { amphigranulata }\end{array}$ & S. platensis \\
\hline 2 & $0.128 \pm 0.01{ }^{n s}$ & $0.12 \pm 0.01 \mathrm{~ns}$ & $0.124 \pm 0.01 \mathrm{~ns}$ & $0.142 \pm 0.01{ }^{n s}$ & $0.158 \pm 0.001^{\mathrm{ns}}$ & $0.152 \pm 0.01^{\mathrm{ns}}$ & $0.164 \pm 0.001^{n s}$ \\
\hline 4 & $0.222 \pm 0.01^{\mathrm{gB}}$ & $0.194 \pm 0.001^{\mathrm{hB}}$ & $0.172 \pm 0.01^{\mathrm{fB}}$ & $0.172 \pm 0.02^{\mathrm{hB}}$ & $0.184 \pm 0.001^{\mathrm{hB}}$ & $0.198 \pm 0.02^{\mathrm{hB}}$ & $0.882 \pm 0.01^{\mathrm{eA}}$ \\
\hline 6 & $0.322 \pm 0.01^{\mathrm{gB}}$ & $0.93 \pm 0.01^{\mathrm{gB}}$ & $1.99 \pm 0.01^{\mathrm{eB}}$ & $1.186 \pm 0.06^{\mathrm{gB}}$ & $1.248 \pm 0.01^{\mathrm{gB}}$ & $0.326 \pm 0.05^{\mathrm{hB}}$ & $2.856 \pm 0.1^{\mathrm{dA}}$ \\
\hline 8 & $1.43 \pm 0.03^{f D}$ & $1.772 \pm 0.05^{\mathrm{fC}}$ & $\begin{array}{c}2.468 \pm 0.05 \\
d B\end{array}$ & $1.828 \pm 0.1^{\mathrm{fC}}$ & $1.986 \pm 0.01^{\mathrm{fC}}$ & $0.918 \pm 0.1 \mathrm{gE}$ & $4.664 \pm 0.1^{\mathrm{cA}}$ \\
\hline 10 & $1.638 \pm 0.05^{f D}$ & $2.2 \pm 0.05^{\mathrm{eC}}$ & $3.174 \pm 0.1^{\mathrm{cB}}$ & $3.008 \pm 0.1^{\mathrm{eB}}$ & $3.482 \pm 0.1^{\mathrm{eB}}$ & $1.842 \pm 0.1^{\mathrm{fD}}$ & $6.362 \pm 0.2^{\mathrm{bA}}$ \\
\hline 12 & $2.578 \pm 0.08^{\mathrm{eD}}$ & $3.846 \pm 0.2^{\mathrm{dB}}$ & $3.664 \pm 0.2^{\mathrm{cC}}$ & $4.184 \pm 0.2^{\mathrm{dB}}$ & $4.28 \pm 0.1^{\mathrm{dB}}$ & $3.18 \pm 0.2^{\mathrm{eC}}$ & $7.764 \pm 0.2^{\mathrm{aA}}$ \\
\hline 14 & $4.078 \pm 0.08^{\mathrm{dD}}$ & $4.918 \pm 0.2^{\mathrm{cC}}$ & $4.318 \pm 0.2^{\mathrm{bC}}$ & $5.556 \pm 0.2^{\mathrm{cB}}$ & $5.818 \pm 0.2^{\mathrm{cB}}$ & $4.022 \pm 0.2^{\mathrm{dD}}$ & $8.312 \pm 0.1^{\mathrm{aA}}$ \\
\hline 16 & $6.384 \pm 0.1^{\mathrm{cC}}$ & $6.018 \pm 0.3^{\mathrm{bD}}$ & $4.938 \pm 0.3^{\mathrm{bE}}$ & $6.838 \pm 0.2^{\mathrm{bC}}$ & $7.23 \pm 0.2^{\mathrm{bB}}$ & $5.982 \pm 0.2^{\mathrm{cD}}$ & $8.322 \pm 0.1^{\mathrm{aA}}$ \\
\hline 18 & $6.904 \pm 0.2^{\mathrm{bC}}$ & $6.442 \pm 0.2^{\mathrm{aC}}$ & $5.93 \pm 0.2^{\mathrm{aD}}$ & $7.84 \pm 0.3^{\mathrm{aA}}$ & $8.214 \pm 0.2^{\mathrm{aA}}$ & $7.592 \pm 0.2^{\mathrm{bB}}$ & \\
\hline 20 & $7.304 \pm 0.2^{\mathrm{aB}}$ & $6.878 \pm 0.3^{\mathrm{aB}}$ & $6.198 \pm 0.2^{\mathrm{aC}}$ & $8.20 \pm 0.1^{\mathrm{aA}}$ & $8.442 \pm 0.2^{\mathrm{aA}}$ & $8.178 \pm 0.1^{\mathrm{aA}}$ & \\
\hline 22 & $7.322 \pm 0.2^{\mathrm{aB}}$ & $6.882 \pm 0.3^{\mathrm{aB}}$ & $6.21 \pm 0.1^{\mathrm{ac}}$ & $8.22 \pm 0.1^{\mathrm{aA}}$ & $8.478 \pm 0.3^{\mathrm{aA}}$ & $8.182 \pm 0.1^{\mathrm{aA}}$ & \\
\hline
\end{tabular}

Values are mean of three replicates $\pm S D$. Values with the same capital letter in the same row showed highly insignificant differences; Values with the same small letter in the same column showed highly insignificant differences at $P \leq 0.05$; ns: nonsignificant result showed in the second day for all species.

Biosynthesis of AgNPs using cyanobacterial sources

Biosynthesis of $\mathrm{AgNPs}$ from $\mathrm{AgNO}_{3}$ is one of the most widely used methods for silver colloid synthesis. This solution, which was initially colorless, turned reddish-brown indicating the biotransformation of ionic silver to the reduced silver, and the subsequent formation of NPs in an aqueous medium. It is well known that AgNPs exhibit a reddish -brown color in aqueous solutions, due to the excitation of surface plasmon vibrations in AgNPs. According to the obtained results, the experimented resources as filtrates and biomasses of all the tested cyanobacterial cultures were able to reduce silver ion to AgNPs as verified by visual and UV spectrophotometry change in color and shown in Figures 2 and 3. 


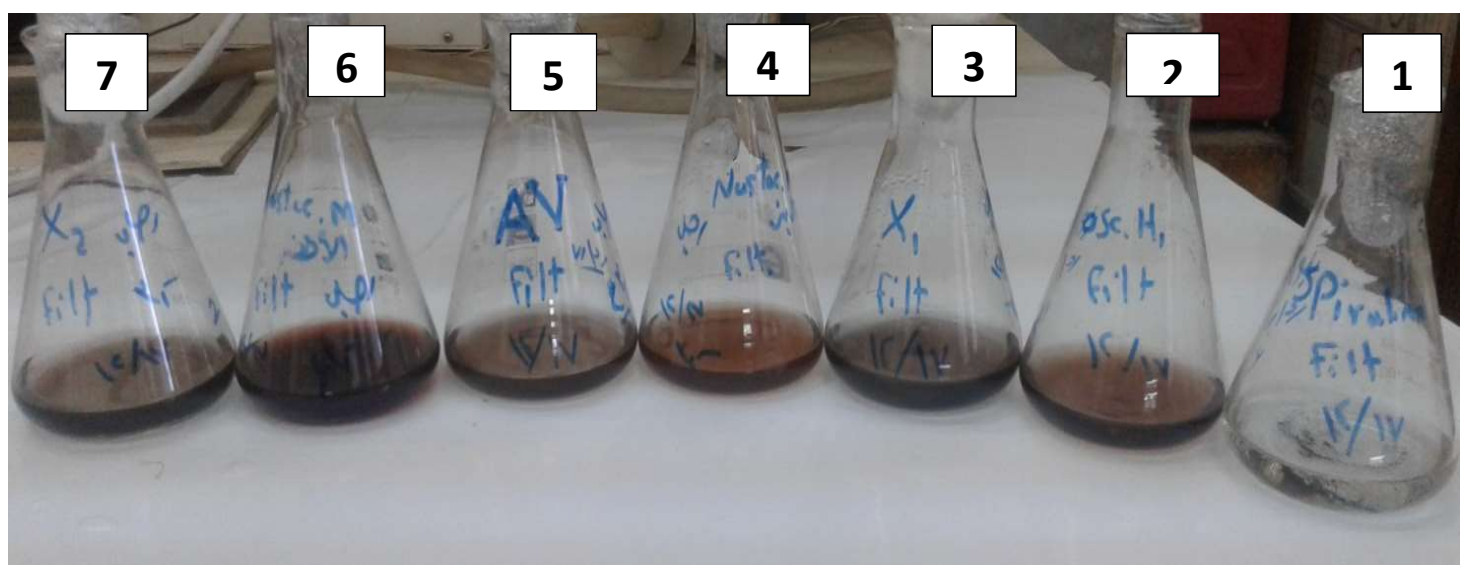

Figure 2: AgNPs biosynthesized by the filtrate of the tested cyanobacterial cultures.

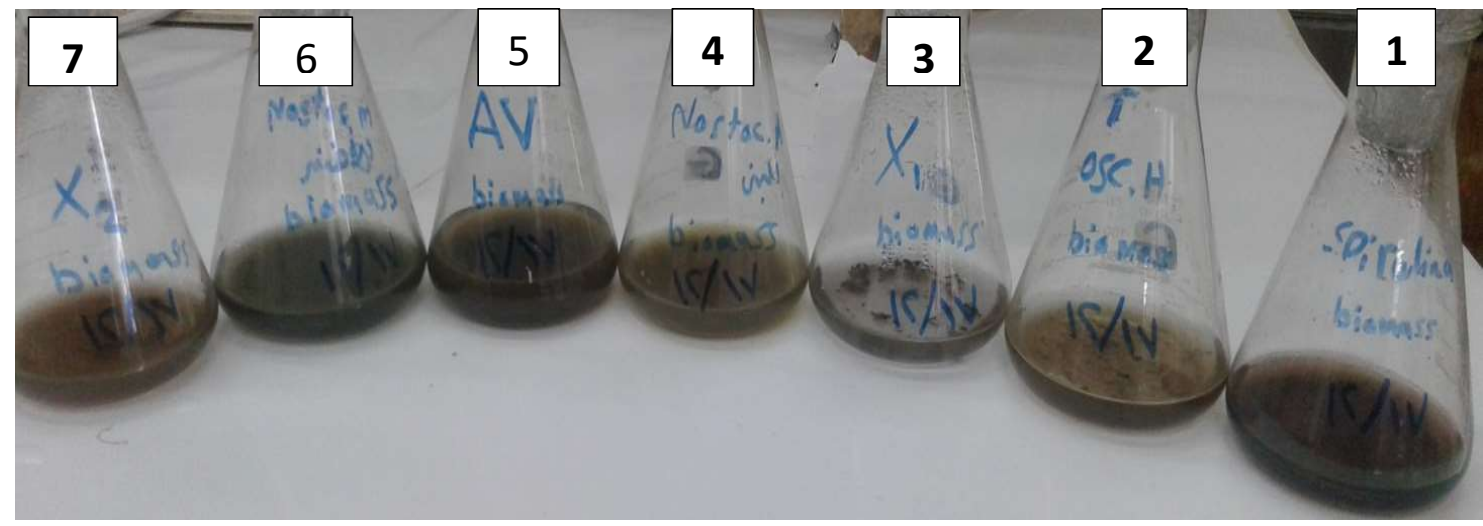

Fig. 3: AgNPs biosynthesized by the tested cyanobacterial biomass 1; S. platensis, 2; 0 . acuminate, 3; O. amphigranulata, 4; N. muscorum, 5; Anabaena variables 6; $N$. linckia, 7; $P$. purpurascens.

\section{Characterization of AgNPs UV-vis Spectrometry}

UV-Vis spectrum is one of the most sensitive and easy way to test the Synthesis of AgNPs. The absorption peak was recorded at time intervals of 24, 48, 72 and 96h. The surface plasmon resonance bands indicated the production of AgNPs which intensity was also dependent on the used algal resource for NPs biosynthesis. The UV-Vis spectrum maximum absorbance occurred at

nearly 400nm for the filtrate (Figure 4 not 6: $a, b, c, d, e, f \& g$ ) and the biomass (Figure 5: a, b, c, d, e, f \& g). These results revealed that the AgNPs dispersed in the aqueous solution with no evidence for aggregation and the formation was dependent on time and concentration of the algal resource solution. 

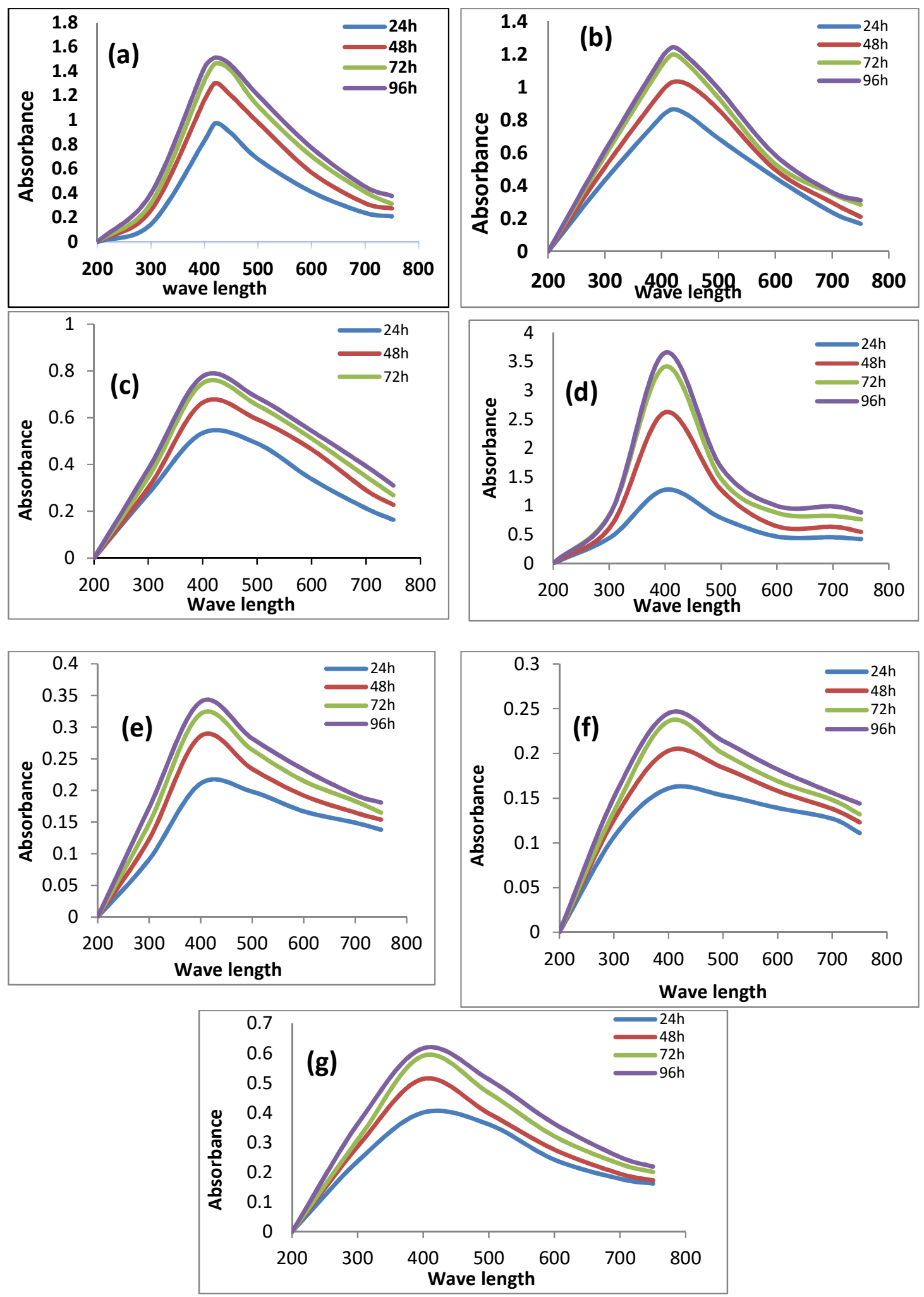

Fig. 4: UV-Vis spectrum of AgNPs biosynthesized by the biomass of each tested cyanobacterial species. a; S. platensis, b; N. linckia, c; N. muscorum, d; $A$. variables e; $O$. acuminate, $\mathbf{f} ; O$. amphigranulata, $\mathbf{g}$; P. purpurascens 

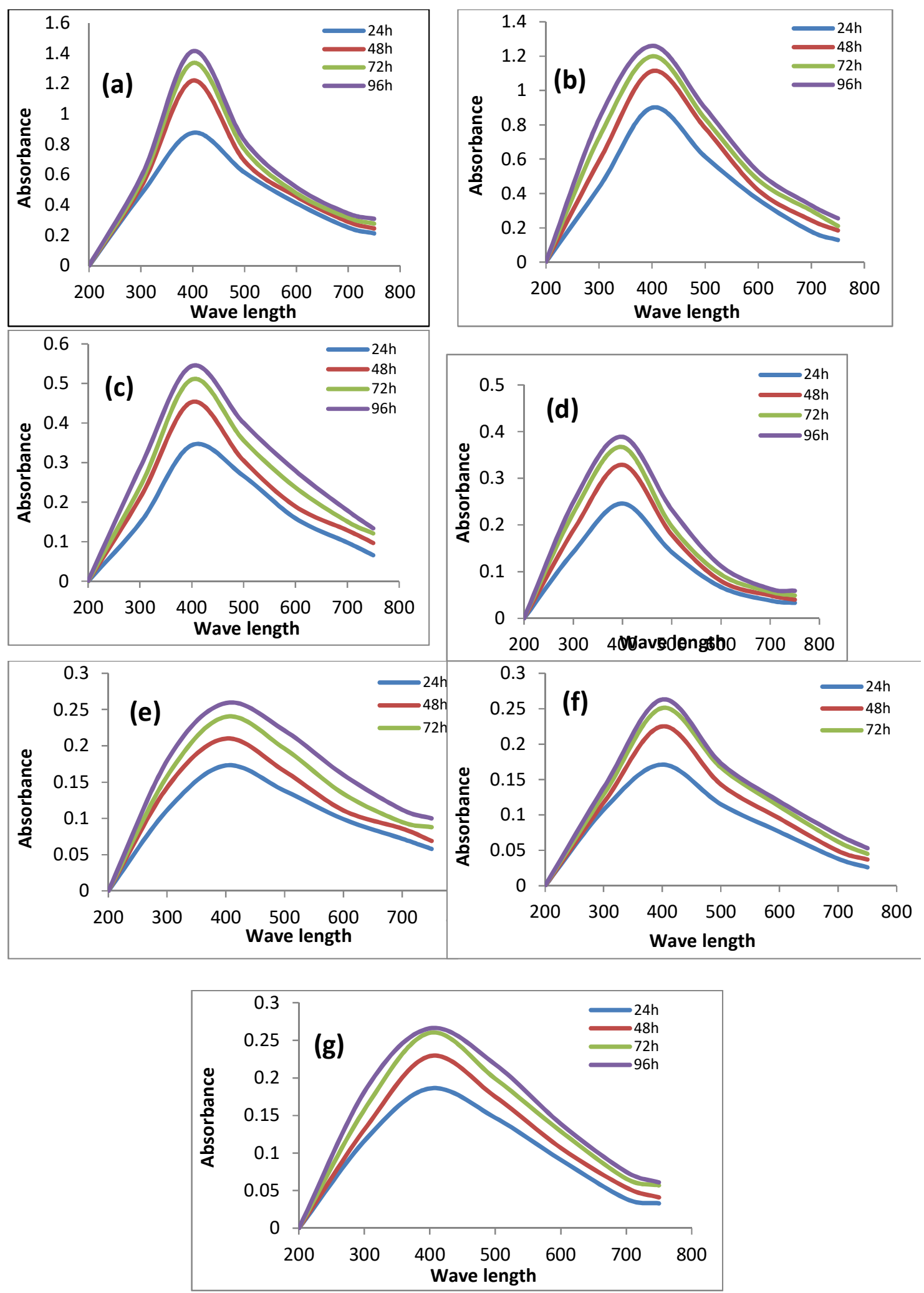

Fig. 5: UV-Vis spectrum of AgNPs biosynthesized by the filtrate of each tested cyanobacterial species. a; S. platensis, b; N. linckia , c; N. muscorum, d; Anabaena variables e; O. acuminate, f; O. amphigranulata, g; P. Purpurascens. 


\section{Discussion}

Cyanobacteria, or blue green algae are phototrophic, nitrogen fixing, ubiquitous, prokaryotic organisms, recognized to be a promising source of renewable fuel, biofertilizers, pigments, colorants, proteins and vitamins. Cyanobacteria have also been reported as a huge repertoire of novel, bioactive natural compounds. The biologically active secondary metabolites include lipopeptides, amino acids, fatty acids, amides, alkaloids and polyketides which possess a wide range of cytotoxic, antiviral, antibiotic, antimycotic, multidrug resistance reversing, immunosuppressive, antiinflammatory, enzyme inhibiting properties (Mukherjee et al., 2013).

The fabrication of silver nanoparticles has been practiced through biological routes as it richer with healthy components (Khalifa et al., 2016). Singh et al. (2014) studied the synthesis of AgNPs from Anabaena doliolum cell extract and reported however, the mechanism how the cyanobacterial cell extract is capable of reducing the $\mathrm{AgNO}_{3}$ solution into AgNPs is not very well known. It is supposed that the enzyme, protein, amino acids and several other groups might be involved in the reduction of $\mathrm{AgNO}_{3}$ solution into the AgNPs (Mubarak-Ali et al., 2012). MubarakAli et al. (2011) suggested that $\mathrm{Ag}^{+}$and $\mathrm{NO}_{3}$ entered the cyanobacteria cells through a transport system and degraded in solution and the presence of AgNPs inside the cytoplasm, $\mathrm{Ag}^{+}$is presumably reduced to $\mathrm{Ag}^{\circ}$ because $\mathrm{AgNO}_{3}$, a toxic reagent, was used in metabolic processes, it ultimately killed the cells. During the death of cyanobacteria, nanoparticles of silver produced inside the cells were release through the cell membrane into solution, as indicated by the precipitation of AgNPs around the cells. The dead cyanobacteria also released organics (protein, and other biochemical) that caused further precipitation of silver from solution outside the cells. The protein molecules act as reducing agent for silver nanoparticles. The protein molecule made up of different functional group in amino acid sequences such as amino, carboxyl, sulfate groups present in the cyanobacterial protein favor the formation of extremely small-sized AgNPs with narrow particle size distribution and hydroxyl and sulfonic groups are beneficial to synthesis of AgNPs with a slightly larger particle size in a weak reducing environment. It has already been certified that the AgNPs can be stabilized and are well functional groups, such as carboxyl, hydroxyl, and amido and thiol group, except the steric effect arising from the large molecular structures of the organic modifier (protein) on the surface of the particles (Vigneshwaran et al., 2007).

In conclusion; the growth rates of cyanobacterial species were determined through optical density and dry weight. The present study verified that filtrate and biomass of 
the selected cyanobacterial species can biosynthesize AgNPs for multipurpose medicinal and pharmaceutical applications.

\section{References}

El-Sheekh, M. M. and El-Kassas, H. Y. (2016). Algal production of nano-silver and gold: Their antimicrobial and cytotoxic activities: a review. Genetic Engineering Biotechnology. 14: 299310.

Ahmed, E. A.; Abdel Hafez, E. H.; Ismail, A. F. M.; Elsonbaty, S. M.; Abbas, H. S. and Salah El Din, R. A. (2015). Biosynthesis of silver nanoparticles by Spirulina platensis \& Nostoc sp. Global Advanced Research Journal of Microbiology. 4(4): 36 - 49.

Phull, A. R.; Abbas, Q.; Ali, A.; Raza, H.; Kim, S. J.; Zia, M. and Haq, I. (2016). Antioxidant, cytotoxic and antimicrobial activities of green synthesized silver nanoparticles from crude extract of Bergenia ciliata. Faseb Journal Phycology Science. 2(1): 31-36.

Abia, S. and Ogawa, T. (1977). Assessment of growth yield of a blue green algae Spirulina platensis in axenic and continuous culture. Journal of Genitics and Microbiology. 102: 179-182.

Reppika, R.; Deruelles, J.; Waterbury, J.; Herdman, M. and Stanier, R. (1979). Generic assignment, strain histories and properties of pure cultures of cyanobacteria. Journal of Genitics and Microbiology. 111:1-61
Stainer, R. Y.; Kunisawa, R.; Mandel, M. and Cohen-Bazire, G. (1971). Purification and properties of unicellular blue- green algae (Chroococcales). Bacteriol. Rev. 35: 171-205

El-Sheekh, M. M. and El-Kassas, H. Y. (2014). Application of Biosynthesized Silver Nanoparticles Against a Cancer Promoter Cyanobacterium, Microcystis aeruginosa. Asian Pacific Journal. Cancer Prevention, 15: 67736779.

Desikachary, T. V. (1959). Cyanophyta. Indian Council Agricultural Research. New Delhi. India.

Mukherjee, G.; Nayak, B. K. and Das, D. (2013). Cyanobacteria as a valuable source of antiviral, antibacterial and antifungal compounds, an overview. Algological studies. 143: 3-25. DOI: 10.1127/1864-1318/2013/0143

Khalifa, K. S.; Hamouda, R. A. and Hamz, H. A. (2016). Antitumor activity of silver nanoparticles biosynthesized by micro algae. Journal of Chemical and Pharmaceutical Research. 8 (3): 16.

Singh, G., Babele, P.K., Shahi, S.K., Sinha, R.P., Tyagi, M.B. and Kumar, A. (2014). Green synthesis of silver nanoparticles using cell extracts of Anabaena doliolum and screening of its antibacterial and antitumor activity. Journal of Microbiology and Biotechnology. 24: 1354-1367. 
Kedia, A.; Prakash, B.; Mishra, P. K. and Dubey, N. K. (2014). Antifungal and antiaflatoxigenic properties of Cuminum cyminum (L.) seed essential oil and its efficacy as a preservative in stored commodities. International Journal of Food and Microbiology. 168: 1-7.

Mubarak-Ali, D.; Gopinath, V.; Rameshbabu, N. and Thajuddin, N. (2012). Synthesis and characterization of Cd-S nanoparticles using Cphycoerythrin from the marine cyanobacteria. Mater Letter Nature. 74: 8-11.
Mubrok-Ali, D. M.; Sasikala, M.; Gunasekaran, M. and Thajuddin, N. (2011). Biosynthesis and characterization of silver nanoparticles using marine cyanobacterium, Oscillatoria willei NTDM01. Digest Journal of Nanomaterials and Biostructure. 6: 385-390.

Vigneshwaran, N.; Ashtaputre, N. M.; Varadarajan, P. V.; Nachane, R. P.; Paraliker, K. M. and Balasubramanya, R. H. (2007). Biological synthesis of silver nanoparticles using the fungus Aspergillus flavus. Mater. Lett. 61: 1413-1418.

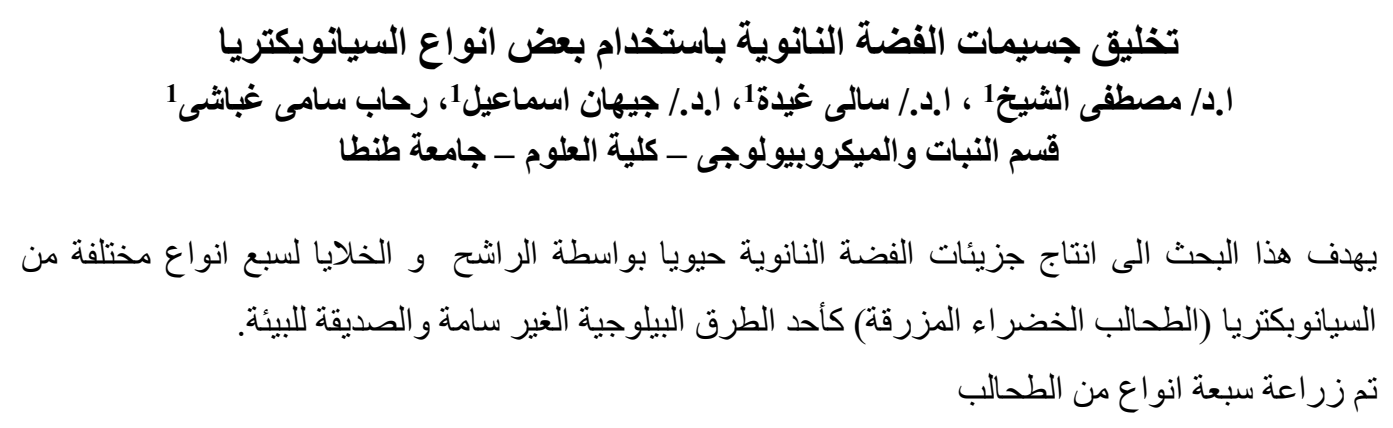

(Nostoc linckia, Nostoc muscorum, Oscillatoria acuminata, Anabaena variables, Oscillatoria amphigranulata, Spirulina platensis and Phormidium purpurascens) فى الوسط الغذائى BG-11 لجميع الطحالب المختارة لمدة 22 يوم باستثناء طحلب S. platensis و الذى تم تنميته فى الوسط الغذائى الخاص به

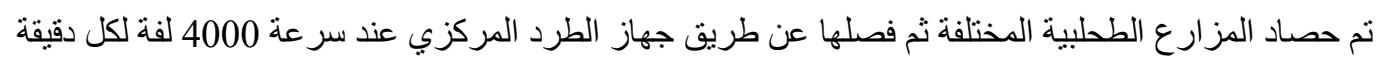
وذللك لمدة 20 دقيقة للحصول على الر اشح والخلايا كل على حدة. ثم استخدام الراشح و الخلايا لتخليق جزيئات

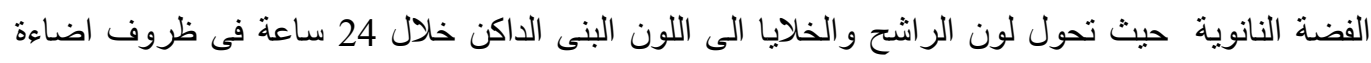
مستمرة مما يدل على تكوين جزيئات الفضة النانوية. كما اوضحت الدراسة التحليلية للجزيئات النانوية المخلقة

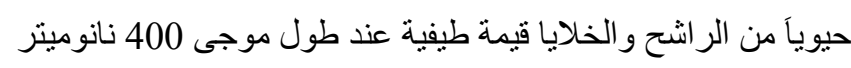

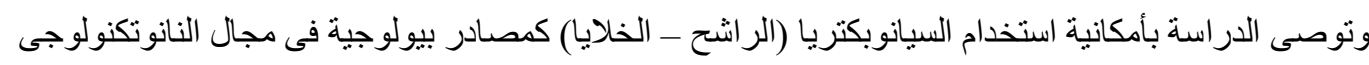

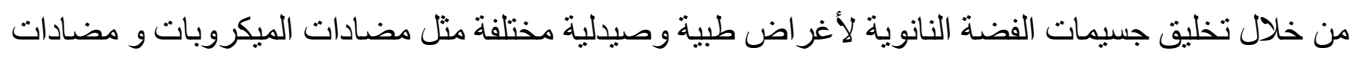
الأكسدة ومضادات الفيروسات. 